\title{
Techniques - Orthotopic kidney transplantation in patients with diseased inferior vena cavas
}

\author{
E. Chan ${ }^{1}$; Alp Sener ${ }^{1,2}$; Vivian C. McAlister ${ }^{1,2}$, Patrick P. Luke ${ }^{1,2}$ \\ ${ }^{1}$ Western University Schulich School of Medicine and Dentistry, Western University, London, ON, \\ Canada; ${ }^{2}$ Department of Surgery, London Health Sciences Centre, Western University, London, ON, \\ Canada; ${ }^{3}$ Multi-Organ Transplant Program, London Health Sciences Centre, Western University, London, ON, \\ Canada
}

Cite as: Can Urol Assoc J 2018 October 15; Epub ahead of print. http://dx.doi.org/10.5489/cuaj.5515

Published online October 15, 2018

$* * *$

\section{Introduction}

Heterotopic renal transplantation is the treatment of choice for patients with end-stage renal disease (ESRD). ESRD may be associated with inferior vena cava (IVC) thrombosis as a consequence of femoral dialysis catheter placement, IVC filter or stent, or hypercoagulable states $^{1}$, precluding renal transplantation into the iliac fossa. In such patients, orthotopic kidney transplantation (OKT) has been described with acceptable rates of complications and reasonable long-term graft outcomes. ${ }^{2-5}$

We review the results of three OKTs performed primarily as a strategy to avoid the lower IVC and iliac vessels. The goal of this report is to describe technical variations in kidney transplantation that can be utilized to approach the diseased IVC and describe their associated functional outcomes.

\section{Methods}

Between 2009-2014, 370 deceased donor and 109 living donor kidney transplants were performed at London Health Sciences Centre by a single surgeon. Three cases of OKT were performed. Clinical data, surgical reports, and complications were collected retrospectively. Patient characteristics, cause of ESRD, indications for OKT, renal graft characteristics, surgical technique, complications, graft function, and patient survival were included in our analysis.

\section{Results}

Patient characteristics, renal disease, and indications for OKT are outlined in Table 1. Mean patient age was 51 years and the mean follow-up was 4.45 years. All were first kidney transplants. Mean age of donor was 43 years; all were standard criteria donors. Technical aspects of OKTs are listed in Table 2. Diagrams of arterial, venous, and urinary anastomoses are found in Figure 1. No patients experienced graft rejection. 


\section{Cases}

Case 1

A 54-year-old female with short gut syndrome secondary to multiple bowel resections related to Crohn's disease. She received a small bowel transplant but developed ESRD secondary to calcineurin inhibitor toxicity. This was complicated by thrombosis of the IVC and SVC. Translumbar dialysis catheter was the last available access point for hemodialysis. She underwent OKT through a retroperitoneal flank incision to avoid the peritoneal cavity. Estimated blood loss was $400 \mathrm{ml}$. Her postoperative course was complicated by a left flank incisional wound infection (Clavien II).

\section{Case 2}

A 44-year-old paraplegic male with ESRD secondary to neurogenic bladder and obstructive uropathy. A femoral dialysis catheter was placed due to loss of hemodialysis access from thrombosis, which led to IVC stenosis requiring placement of IVC stent. He had previous cystoprostatectomy with ileal conduit. Vascular reconstruction was performed with a donor carotid artery extension and donor caval extension. Ureteral anastomosis was performed to a stenotic ileal conduit that required reconstruction. The operation was 8 hours in duration with 3 units of blood transfused. The postoperative course was complicated by wound dehiscence (Clavien IIIa). He died 5 years later from cardiovascular disease with functioning allograft.

\section{Case 3}

A 69-year-old male developed ESRD secondary to obstructive uropathy from idiopathic retroperitoneal fibrosis. He also had IVC thrombosis from an IVC filter. Intraoperatively, the lower aspect of the great vessels was found to be encased in retroperitoneal fibrosis, particularly around the IVC filter. A donor iliac artery jump graft was used to lengthen the donor kidney artery approximately $10 \mathrm{~cm}$ and was anastomosed to the right common iliac artery (Figure 2.). The donor renal vein with caval extension was anastomosed to the right renal vein. The long vascular conduits allowed the donor ureter to be anastomosed to the bladder. The estimated blood loss was 500-700 ml. Postoperatively, this patient had delayed graft function and developed abdominal hematomas requiring transfusion of 4 units of blood (Clavien II). 


\section{Discussion}

OKT for IVC thrombosis was first described in 1976 by Mozes et al. ${ }^{6}$ Since the introduction of this approach, there have been reports of stable graft function up to 6 months. ${ }^{7}$ However, there has been limited reports of OKT in adults with IVC disease with long-term follow-up. ${ }^{8}$ To our knowledge, this is the largest case series of OKT indicated for the diseased IVC with long-term follow-up. We present three cases ok OKT with different surgical approaches for vascular and urinary tract reconstruction.

Arterial reconstruction during OKT can be achieved through anastomosis of the donor renal artery to the native splenic, renal, or hepatic artery, as well as the aorta. ${ }^{9}$ In our series, we utilized donor carotid artery extension and iliac artery extension for anastomosis to the right common iliac artery in separate cases. In one case, a donor kidney with 3 separate vessels were conjoined as a single unit for anastomosis. Although the splenic artery and aorta were not used in this series, we were prepared to utilize these vessels.

Venous reconstruction was achieved through anastomosis of the donor renal vein, with or without donor IVC extension, to the native renal vein. In the setting of OKT for IVC thrombosis, venous anastomosis to the splenic vein, inferior mesenteric vein, superior mesenteric vein, and native renal vein have been described. ${ }^{7,8,10}$ It is possible that a portion of the external iliac vein that was free of thrombus could have utilized in these cases, but this was avoided due to limited ability to exclude venous thrombus, high venous resistance (despite collaterals), or vascular injury.

Options for urinary drainage during OKT include pyelo-ureterostomy and ureteroureterostomy. ${ }^{2}$ In this series, reconstruction was performed by anastomosis of the donor renal pelvis or ureter to the recipient ureter, bladder, and ileal conduit, respectively. Donor ureteral anastomosis was performed to the native bladder in Case 3 due to history of retroperitoneal fibrosis. Adequate ureteral length was obtained while avoiding the risks of stenosis and devascularization related to anastomosis to an encased native ureter.

Complication rates in our series and other have been significant. Reported complications from OKT include: arterial stenosis, urinary fistulas, urolithiasis, arterial and venous thrombosis, and reflux nephropathy. ${ }^{2}$

\section{Conclusion}

OKT is a viable approach for patients with ESRD who cannot undergo heterotopic kidney transplantation due to thrombosis, stenosis, or stenting of the IVC with acceptable long-term functional outcomes. Different approaches to arterial, venous, and urinary tract reconstruction are viable for patients with anatomical complexities such as multiple arteries, short veins, retroperitoneal fibrosis, or urinary diversions. 


\section{References}

1. Alkhouli M, Morad M, Narins CR, Raza F, Bashir R. Inferior Vena Cava Thrombosis. JACC: Cardiovascular Interventions 2016;9:629-43.

2. Hevia V, Gomez V, Alvarez S, Diez-Nicolas V, Fernandez A, Burgos FB. Orthotopic kidney transplant: a valid surgical alternative for complex patients. Curr Urol Rep 2015;16.

3. Paduch DA, Barry JM, Arsanjani A, Lemmers MJ. Indication, surgical technique and outcome of orthotopic renal transplantation. J Urol 2001;166:1647-50.

4. Musquera M, Peri LL, Alvarez-Vijande R, Oppenheimer F, Gil-Vernet JM, Alcaraz A. Orthotopic kidney transplantation: an alternative surgical technique in selected patients. Eur Urol 2010;58:927-33.

5. Cornejo F, Arango O, Talbot-Wright R, Carretero P, Gil-Vernet JM. Ileal conduit and orthotopic renal transplantation. An alternative in pathology of the nonviable lower urinary tract. Eur Urol 1988;14:77-9.

6. Mozes MF, Kjellstrand CM, Simmons RL, Najarian JS. Orthotopic renal homotransplantation in a patient with thrombosis of the inferior vena cava. The American Journal of Surgery 1976;131:633-6.

7. Patel P, Krishnamurthi V. Successful use of the inferior mesenteric vein for renal transplantation. American journal of transplantation : official journal of the American Society of Transplantation and the American Society of Transplant Surgeons 2003;3:1040-2.

8. Aguirrezabalaga J, Novas S, Veiga F, et al. Renal transplantation with venous drainage through the superior mesenteric vein in cases of thrombosis of the inferior vena cava. Transplantation 2002;74:413-5.

9. Novick AC, Banowsky LH, Stewart BH, Straffon RA. Renal revascularization in patients with severe atherosclerosis of the abdominal aorta or a previous operation on the abdominal aorta. Surg Gynecol Obstet 1977;144:211-8.

10. Rizzello A, Smyth O, Patel N, Reddy S, Sinha S, Vaidya A. Successful Splenic Venous Drainage for Kidney Transplant in Case of Inferior Vena Cava Thrombosis. Transplantation 2011;92:e59-e60. 


\section{Figures and Tables}

Fig. 1. Diagrams for orthotopic kidney transplants (OKT) performed in current series. (A) Case 1 OKT with left donor kidney. (B) Case 2 OKT with right donor kidney; ureteral anastomoses to ileal conduit. (C) Case 3 OKT with right donor kidney.

A)

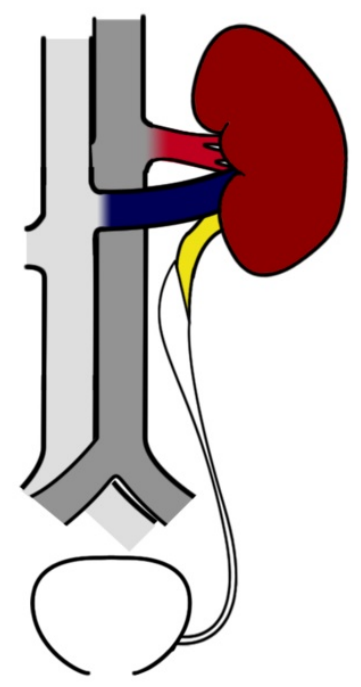

B)

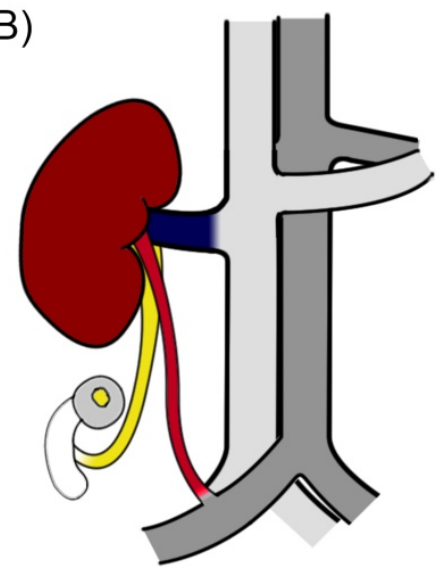

C)

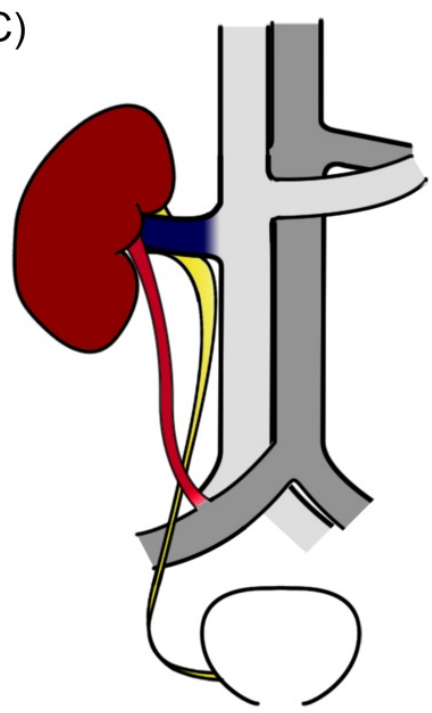


Fig. 2. Intraoperative photograph of Case 3 showing the arterial anastomosis of donor iliac artery jump graft to right common iliac artery, and venous anastomosis of renal allograft to native right renal vein (left) with labelled anatomical diagram (right).

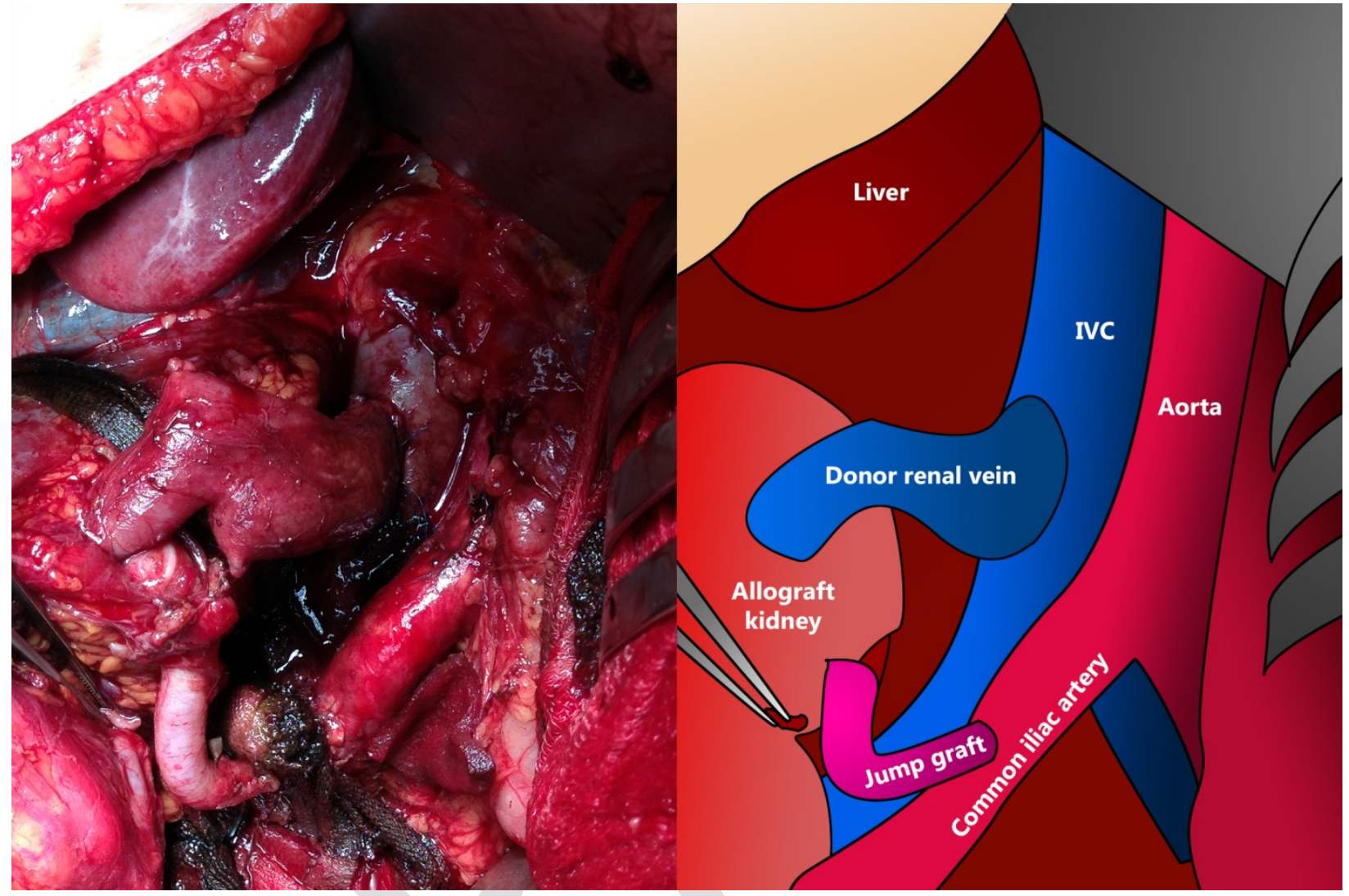




\begin{tabular}{|c|c|c|c|}
\hline & Case 1 & Case 2 & Case 3 \\
\hline Recipient age & 54 & 44 & 69 \\
\hline Recipient sex & $\mathrm{F}$ & M & M \\
\hline Recipient renal disease & $\begin{array}{c}\text { Drug } \\
\text { nephrotoxicity }\end{array}$ & $\begin{array}{c}\text { Obstructive } \\
\text { uropathy }\end{array}$ & $\begin{array}{c}\text { Obstructive } \\
\text { uropathy }\end{array}$ \\
\hline Indication for OKT & $\begin{array}{c}\text { IVC } \\
\text { thrombosis } \\
\end{array}$ & $\begin{array}{c}\text { IVC } \\
\text { stenosis/stent } \\
\end{array}$ & $\begin{array}{c}\text { IVC } \\
\text { thrombosis } \\
\end{array}$ \\
\hline Donor type & SCD/NDD & SCD/NDD & SCD/DCD \\
\hline Donor age & 41 & 36.6 & 51.4 \\
\hline Side transplanted & Left & Right & Right \\
\hline Serum creatinine, 1 year $(\mu \mathrm{mol} / \mathrm{L})$ & 136 & 62 & 154 \\
\hline Serum creatinine, 3 years $(\mu \mathrm{mol} / \mathrm{L})$ & 130 & 65 & 238 \\
\hline Followup duration (years) & 2.89 & 5.39 & 5.08 \\
\hline Death & No & Yes & No \\
\hline
\end{tabular}

DCD: donation after cardiac death; IVC: inferior vena cava; NDD: neurologic determination of death; SCD: standard criteria donor. 


\begin{tabular}{|c|c|c|c|c|c|}
\hline Case & Incision & $\begin{array}{c}\text { Arterial } \\
\text { reconstruction }\end{array}$ & $\begin{array}{c}\text { Venous } \\
\text { reconstruction }\end{array}$ & $\begin{array}{l}\text { Urinary tract } \\
\text { reconstruction }\end{array}$ & $\begin{array}{l}\text { Additional } \\
\text { procedures }\end{array}$ \\
\hline 1 & $\begin{array}{l}\text { Left flank } \\
\text { retroperitoneal } \\
\text { incision }\end{array}$ & $\begin{array}{c}\text { Three renal } \\
\text { artery branches } \\
\text { reconstructed } \\
\text { for anastomosis } \\
\text { end-to-end } \\
\text { with recipient } \\
\text { left renal artery }\end{array}$ & $\begin{array}{l}\text { Left donor } \\
\text { renal vein } \\
\text { anastomosed to } \\
\text { native renal } \\
\text { vein }\end{array}$ & $\begin{array}{l}\text { Donor renal } \\
\text { pelvis } \\
\text { anastomosed to } \\
\text { the native } \\
\text { ureter }\end{array}$ & $\begin{array}{l}\text { Retroperitoneal } \\
\text { strip mesh } \\
\text { reinforcement }\end{array}$ \\
\hline 2 & $\begin{array}{l}\text { Chevron } \\
\text { incision }\end{array}$ & $\begin{array}{l}\text { Donor carotid } \\
\text { artery } \\
\text { extension graft } \\
\text { for anastomosis } \\
\text { between donor } \\
\text { renal artery and } \\
\text { right common } \\
\text { iliac artery }\end{array}$ & $\begin{array}{c}\text { Caval } \\
\text { extension of } \\
\text { donor renal } \\
\text { vein } \\
\text { anastomosed to } \\
\text { native renal } \\
\text { vein }\end{array}$ & $\begin{array}{c}\text { Donor ureter } \\
\text { anastomosed to } \\
\text { reconstructed } \\
\text { ileal conduit }\end{array}$ & Nephropexy \\
\hline 3 & $\begin{array}{l}\text { Midline } \\
\text { incision }\end{array}$ & $\begin{array}{c}\text { Donor iliac } \\
\text { artery } \\
\text { extension } \\
\text { anastomosed to } \\
\text { right common } \\
\text { iliac artery }\end{array}$ & $\begin{array}{c}\text { Caval } \\
\text { extension of } \\
\text { donor renal } \\
\text { vein } \\
\text { anastomosed to } \\
\text { native renal } \\
\text { vein }\end{array}$ & $\begin{array}{l}\text { Donor ureter } \\
\text { anastomosed to } \\
\text { native bladder }\end{array}$ & $\begin{array}{l}\text { Nephropexy } \\
\text { and ventral } \\
\text { hernia repair }\end{array}$ \\
\hline
\end{tabular}

